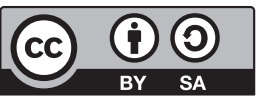

DOI 10.31261/IJREL.2018.4.1.05

\title{
Svetlana Skvortsova
}

Ukraine (ORCID: 0000-0003-4047-1301)

\section{Tetiana Britskan}

Ukraine (ORCID: 0000-0001-7277-4169)

\section{Training for Future Primary School Teachers to Use the Learning Apps Service in Teaching Mathematics}

\begin{abstract}
The article investigates the problem of future primary school teachers' training in using information technology (IT) in teaching mathematics and, in particular, in the aspect of the use of various online resources, online services for teachers, and other pedagogical software. The results of the diagnosis of conditions for future teachers' training for the introduction of IT at the mathematics lessons in primary school are analysed. The peculiarities of the digital generation of children are determined, and, based on this, the necessity of the introduction of IT in mathematics lessons is substantiated. Finally, the approaches to training for future teachers to create interactive exercises - in particular through the Learning Apps online service - are identified.
\end{abstract}

Ke y w ord s: information technologies, training for future teachers, online services Learning Apps, interactive exercises 


\section{Introduction}

The main feature of the modern stage of development of the education system of Ukraine is its integration into the European educational space, which involves the harmonisation of national educational standards with international ones, based on a competent approach in education and envisaging the acquisition of key competences by future specialists. The list of the eight key competences outlined in the Recommendations of the European Parliament and the Council of Europe of 12 December 2006 also includes information competence.

The current notion of information competence or of information and digital competence is the term "digital competence," which includes the confident, critical, and responsible use of and interaction with digital technologies for learning, work, and life in society ("Proposal for a Council Recommendation on Key Competences for Lifelong Learning...," 2018). The term "digital competence" has been applied in the updated edition of key competences for lifelong learning approved by the European Parliament and the EU Council in 2018. Therefore, approaches to the formation of information and communication (digital) competence of teachers are in the field of interest of international organisations (UNESCO, Organization for Economic Cooperation and Development, Eurydice educational networks, European Schoolnet, etc.). The researchers have also focused their attention on the rebuilding of training courses in order to effectively capture future IT teachers in line with the current level of information society development. And this is logical, as representatives of the new digital generation, or "kids of Google," have come to school - these are children born after 2010, in the era of digital technologies and wireless communication. They are surrounded by computers, laptops, tablets, smartphones, and game consoles, and they are simultaneously in the two worlds - both real and virtual, because they cannot imagine their existence without gadgets and connection to the Internet. Modern children are much better than their grandmothers and grandfathers - they work with mobile phones and tablets; they intuitively handle a web search, finding the right cartoons, games, and more, and even trying to learn from online sources on their own. A quick search on the Internet for a lot of information is a feature of modern junior schoolchildren, which is lacking in previous generations.

The interaction of children with IT from an early age directly affects the formation and development of their higher mental functions. Neurophysiologists have found that gadgets, on the one hand, provide quick access to information that requires a certain level of development of cognitive processes for its processing and, on the other hand, have a negative effect on the quality of memory, attention, and information processing in pupils.

Psychological peculiarities of junior schoolchildren - representatives of the digital generation - were the subject of research conducted in the laboratory of 
psychodiagnostics of the GS Kostyuk Institute of Psychology of the National Academy of Educational Sciences of Ukraine (Goncharenko, Vavrik, \& Vereshchak, 2014). Larysa Kondratenko and Lidiia Manilova found that, on the one hand, the feature of students of the digital generation is saturation of information and, on the other hand, there is a constant need for new information, which, unfortunately, they do not try to analyse or memorise.

Scientists note that cognitive processes of the representatives of the digital generation are worse than in previous generations (Bezrukih, 2003, p. 2). The deterioration of memory is due to the fact that students do not need to store information, including learning, because "Google knows everything." In modern junior pupils, there is a decrease in the volume of auditory memory, so it is much more difficult for them to learn poetry and rules by heart. Relying on the work of Daniel Wegner, the psychologist Betty Sparrow of Columbia University suggests that the Internet has become a special form of memory, that is, transactional memory (Sparrow, Liu, \& Wegner, 2011). Representatives of the digital generation do not remember the information they need, but the one they can reach.

Fast flipping of electronic pages, or "computer surfing" (Kim et al., 2010), not perceiving large texts, scanning the first, middle, and final lines of the text, wishing to quickly find out the basic idea without trying to resort to logical processing of the text, rapid switching from one source to another - all these negatively affect the quality of attention and information processing since a person is not accustomed to concentrating on and deeply analysing information.

Another feature of modern children is "clip thinking." Werner Heisenberg, quoted by Marshall McLuhan, notes that "the far-reaching changes in our environment and in our way of life wrought by this technical age have also changed dangerously our ways of thinking, and that here lie the roots of the crises which have shaken our times" (McLuhan, 1962, p. 29). Such thinking is characterised by the use of visual images or associations of different kinds. One of the signs of clip thinking is linguistic minimalism: verbal expression of thoughts is minimised, with a virtually complete substitution of speech by schemes, drawings, and symbols. An example of such communication of modern children is the reflection of thoughts with the help of smilies.

Modern junior schoolchildren are accustomed to a continuous stream of information, and start to get bored when it is not sufficient or it is given very slowly and in a standard way. The digital generation of children is a multitasking generation that has the inherent ability to perform two or more actions simultaneously, but this multitasking is imaginary since the child's brain is not focused on any of them.

Electronic pages, video games, and cartoons offer children a bright, dynamic image and special effects. The brain of the child gets used to high levels of stimulation, which traditional training cannot provide, so it seems uninteresting to students. Teachers are observing that traditional methods of teaching are not working as effectively as before; also, parents turn to the authors of textbooks with 
a request to create an electronic textbook because the child is willing to perform tasks submitted electronically.

It becomes apparent that the digital education model for children should be tailored to take into account pupils' capabilities and needs, which requires updating IT-based learning tools and techniques. In order to meet the students' need for action in the virtual world, it is necessary to change learning tools by including electronic applications such as interactive tasks created on the learningapps.org platform. Obviously, in order to do so, teachers themselves need to know IT well, but usually the teachers of modern-day children of the digital generation are representatives of non-digital generations.

Consequently, there is a need for the training of primary school teachers to use electronic learning tools in the learning process. Analyses of scientific sources on the use of IT in the educational process of general education institutions (Myroslav Zhaldak, Dominika Żezługa, Natalia Morse, Dana Orszagová, Eugenia SmyrnovaTrybulska, etc.), and on creation and use of computer training programmes, electronic textbooks, manuals, presentation and testing programmes (Martin Drlík, Peter Švec, Júlia Tomanová, Martin Cápay, Oksana Kravchuk, Luibov Petukhov, etc.) testify that in the scientific plane a foundation has been created for the development of a methodology for the preparation of future teachers. Meanwhile, this problem has remained inadequate in terms of the use of various online resources, online services for elementary school teachers, and other pedagogical software tools in the process of teaching junior pupils of mathematics.

\section{Theoretical and Practical Principles of the Training of Future Primary School Teachers to Use IT in Mathematics Education}

IT has become an integral part of the training of future professionals in higher education institutions, creating an informational educational environment that includes software that combines teachers and students. It contains a database, educational content, a discussion forum, a test repository, and a student login system (Smyrnova-Trybulska et al., 2017).

The analysis of the concepts of "information technology," "information technology in education," "information technology training," "computer technology," "new information technologies," and "new information technologies in education" is given in the works of Svitlana Skvortsova and Marina Haran (Skvortsova \& Haran, 2015). The authors state that the most common notion in this list is the notion of "information technology" and emphasise the possibility of using it to refer to 
any of the above concepts. In our study, we use the term "information technology" and, following Myroslav Zhaldak (Zhaldak, 2005), we interpret it as a collection of methods and technical means for the collection, organisation, storage, processing, transmission, and presentation of data that increase the level of knowledge of people and develop their capabilities in the management of technical and social processes.

Thus, following the definition of information technology by Zhaldak, we consider the training of future primary school teachers to use information technology in the process of teaching mathematics pupils to be one of the components of methodological training, the purpose of which is to prepare them for the use of various online resources, online services for teachers, and other pedagogical software in their professional activities.

Methodical training is carried out in the process of mastering the discipline "Methodology of teaching mathematics" by future teachers of primary school and during the pedagogical practice. Yet, as shown in the analysis of the programmes of the course of this discipline, carried out during the staging experiment in 2012-2014 in 12 universities of Ukraine by Skvortsova and Haran, there are significant differences in the content of this discipline, but the common point is that the application of information technology in the process of teaching younger students of mathematics is not the subject of separate consideration (Skvortsova \& Haran, 2015).

Meanwhile, the peculiarities of modern children, who are representatives of the digital generation, and world trends in the development of education indicate the need to include the use of various online resources, online services for teachers, and other pedagogical software tools to the content of methodological training. Benchmarks for ICT teacher training curricula are developed by the Netherlands scientists Paul Kirschner, Iwan Wopereis, and Peter Van den Dool, and one of the areas is the consideration of ICT as a means of learning. The researchers emphasise that teachers need to acquire competencies in adapting technology to more effective teaching, planning individual and group activities, preparing and creating teaching materials using ICT, etc. (Kirschner, Wopereis, \& Van den Dool, 2002).

In Poland in 2003, the IT Teacher Training Standard was adopted; it defines the tasks and specifics of the preparation of different groups of teachers for the introduction of IT, depending on the specialty and the educational stage they are working on. In the majority of European countries, as well as in Australia, Canada, and other countries, standards for information and communication competences of future teachers have already been adopted.

An interesting project for our study is the Continuing Professional Development Initiative for Immigrant Teachers to Use IT in Ireland, developed by the National Centre for Technology in Education. It is built on a three-stage approach: from basic skills, through professional skills, to the development of pedagogical skills (National Centre for Technology in Education, 2008).

Therefore, the use of IT is necessary for the effective professional activity of the primary school teacher. Today, IT provides the teacher with an opportunity 
to create interactive exercises, tests, quizzes, and educational games on their own with the help of various online resources, services, and other pedagogical software. For example, there are online services for creating tests and quizzes of various formats: Moodle, Google Forms, Webanketa, Online Test Pad, GoConqr, PlayBuzz, Baamboozle, to name a few. The teacher can use such mobile services as Kahoot!, Triventy, Socrative, or Quizalize to develop educational tests and quizzes on mathematics. The teacher can create educational and game exercises on various subjects using the following online services: ProProfs, Purpose Games, H5P, Flippitty, Learning Apps, etc.

At this time, there are quite a few online services (for instance https://www. google.com/intl/ru_ua/forms/about/, http://pochatkowa.blogspot.com/, https:// ru.padlet.com/, http://en.linoit.com/, https://hisissand.com/, https://www.class roomscreen.com/) addressed to the teacher, and in particular to the elementary school teacher. These services allow the teacher to create educational content, taking into account the peculiarities of the students of the digital generation.

\section{Diagnosis of the State of Preparation of Future Teachers for the Introduction of IT at Mathematics Lessons in Primary School}

Experimental work was carried out on the basis of South Ukrainian National Pedagogical University named after K. D. Ushynsky and Izmail State University of Humanities. The pilot questionnaire was attended by $1003^{\text {rd }}$ year full-time students of the specialty 013 Primary Education. The experimental research consisted of the following stages: stage I - demonstrating the interactive exercises created on the Learning Apps to students; stage II - familiarising students with the possibilities of the Learning Apps service and the algorithm of working with it; stage III - practical training for students to create interactive exercises on different platforms of the Learning Apps service; stage IV - creating individual projects.

Since the definition of the level of development of skills in the use of IT is not the subject of the mentioned experimental research, we confined ourselves to the students' self-esteem. To diagnose the basic skills and skills that will be used in the process of preparing future teachers for the introduction of IT in mathematics lessons in primary school, we have developed an appropriate questionnaire with different types of questions. The questions of the developed questionnaire also gathered general data on respondents and on certain practical skills.

One of the questions in the questionnaire asked students to evaluate their IT skills on a five-point scale, where 5 - excellent, 4 - good, 3 - satisfactory, 2 - 
sufficient, and 1 - unsatisfactory. As a result of the analysis of questionnaires, we have established that all students have a computer with the Internet connection and have experience in using information technology in their teaching activities. Most students can work with e-mail and programmes to work with different types of documents (texts, spreadsheets, presentations) in the Microsoft Office suite. What has been revealed as significantly worse are self-assessments of students' abilities to work in professional online networks and to create websites. The results of the study are presented in Figure 1.

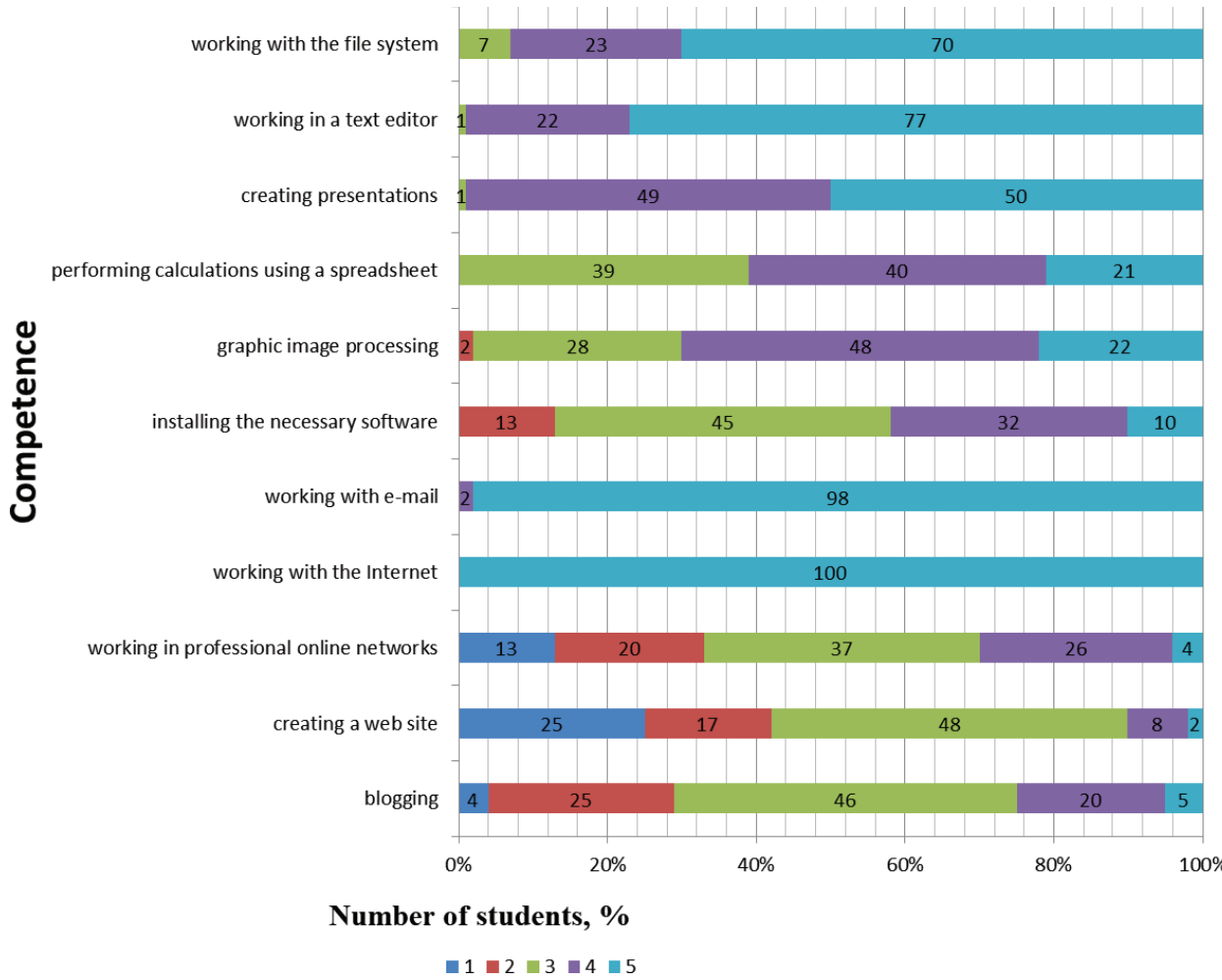

Figure 1. Self-assessment by students of the level of knowledge of information technologies.

S o u r c e : Own work.

Analysing the answers to this questionnaire, one can conclude that students have basic knowledge and IT skills acquired during the process of studying at school and at a higher education institution.

At the same time, we were interested in the issue of the orientation of future teachers on the use of IT in professional activities. It should be noted that before the experiment, students had the experience of using multimedia presentations at the lectures on methods of teaching mathematics, using information provided on 
special Internet sites, in social groups, on YouTube, etc., in order to master this discipline.

Before starting to experiment with the Learning Apps online service and learning how to work with it, students were asked to identify which uses of IT tools they considered appropriate in primary school mathematics education, in the form of an open question: "What Web resources do you use for teaching materials?" Responding to it, the students listed the following: https://skvor.info/, http:// www.yrok.net.ua/, http://ru.osvita.ua/, http://begin-english.ru/, https://www. youtube.com, and other sites. However, for the professional training of a future teacher, this list of Web-resources is rather limited.

We were also interested in the understanding of the need for future teachers to use IT in the training of modern junior pupils. 97 students think that it is beneficial to use educational games, 94 - multimedia presentations, 91 - interactive exercises, 85 - educational videos and audio recordings, 73 - training programmes, 40 - tests and quizzes. Consequently, most students agree that it is necessary to introduce IT in the education of modern-day pupils.

Concerning the use of various gadgets for junior school pupils in mathematics, 68 students consider it expedient to use them (smartphones, tablets, electronic books). However, with regard to working with special didactic technical means of teaching, we should note that most students are not aware of the opportunities of working with them, and therefore do not have the appropriate skills and experience with them (for instance, with the interactive whiteboard). 88 students claim that they have never used the interactive whiteboard in educational activities, and this is logical, since many Ukrainian educational institutions do not have the opportunity to purchase this expensive equipment.

Despite the fact that students did not have the skills to work with IT-based learning tools, it is pleasing that most students expressed their willingness to participate in creating interactive exercises using the Learning Apps (96\%).

The results of our study indicate that students have basic knowledge, skills, IT skills, and readiness to improve them and, in particular, to learn how to create interactive exercises with the Learning Apps service.

\section{Preparing Future Primary School Teachers to Create Interactive Mathematics Exercises Using Learning Apps}

\section{Learning Apps as a Tool for Teaching Mathematics to Junior Schoolchildren}

The Internet network attracts teachers with their information resources and services. The most popular at this stage are Web 2.0 social services. Web 2.0 generally covers the services that allow users to generate content themselves, as 
well as to distribute it using tapes and hyperlinks. The user chooses which content he or she should get on the go, set up for reading selected blogs, community participation, etc. ("Ŝo take Web?...," 2009).

LearningApps.org is one of the Web 2.0 services to support learning that makes it easy to create online interactive exercises. Its purpose is to create a public library of independent blocks, suitable for reuse and editing (Hielscher, 2012).

In order to create interactive exercises on the Learning Apps service, the teacher needs to go to https://learningapps.org/, register, and link his or her account with the email in case of password recovery. Opening the service, the user immediately finds the menu of the site - a list of hyperlinks to its sections: "View Exercises," "Creating Exercises," "My Classes," and "My Exercises." Depending on its purpose, the teacher chooses the desired section. By opening the section "Review of Exercises," one has an opportunity to see a collection of exercises that are distributed at the level (depending on the age-old features of the education curriculum: pre-school, primary, secondary, high school, and postgraduate education) and categories (study subjects: English, mathematics, computer science, art, etc.).

When we choose the "Creating Exercises" section, the service introduces us to a collection of platforms through which we can create interactive exercises, such as: find a couple, classification, numeric line, simple ordering, free text response, image snippets, quiz, and fill in the gaps. In addition to the abovementioned platforms, the service also contains templates for creating interactive games and quizzes, collections of exercises, audio and video content, exercises such as the first million, puzzles, crosswords, find on map, find the words, where is it?, guess the word, horse racing, game of the couple, calculate.

Learning Apps provides great opportunities for a primary school teacher to create interactive math exercises. Interactive exercises can cover all sections of the initial course of mathematics - the numbering of non-negative integers and ordinary fractions, arithmetic operations of addition, subtraction, multiplication, and division with integers, magnitudes, plot mathematical problems, as well as algebraic and geometric propaedeutic.

When studying the numbering of natural numbers and regular correct fractions, it will be best to use interactive exercises performed using the "Easy Ordering" platform, which includes an analysis of proposed objects (figures, numbers, etc.) and the establishment of a certain sequence of their placement (Skvortsova \& Onoprienko, 2017, p. 70). To create an exercise of this type, one needs to choose the appropriate platform. Next, the service offers one to familiarise with three examples of exercises of this type: if the user likes a certain exercise, then he or she has the opportunity to create his her own exercise on its basis, replacing only the necessary values. One can also skip this step and select the "create new exercise" function; the user fills the platform by entering the necessary data: he or she gives the name (Exercise 1) and the description of the task (Place the figures with the numbers in the order of their growth). The next step is to specify the items 
that will be placed in the specified order. Depending on the number of items, one fills out the appropriate number of cards with the required information (it may be text, images, voice over, audio, and video) and indicates the order of their location (from _ to __) (Figure 2). One must also choose the way in which elements are displayed (free, upright, or horizontally). The final step is to write a feedback text that will appear when the correct solution is found, as well as writing the text for the prompts. Next, one completes the editing and goes over to it (Figure 3). If everything turns out as planned, one saves the exercise, and if there are certain disadvantages, then one returns to its editing.

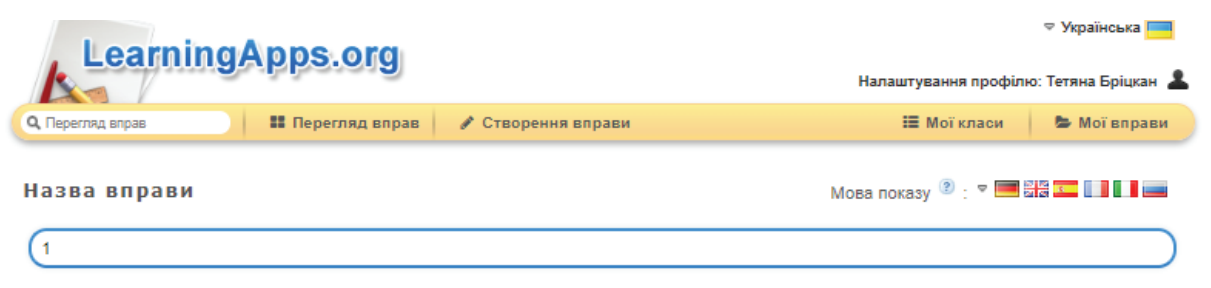

Опис завдання

Напишіть опис завдання ціеї вправи, який показуватиметься при ї̈ запуску. Можна залишити поле порожнім.

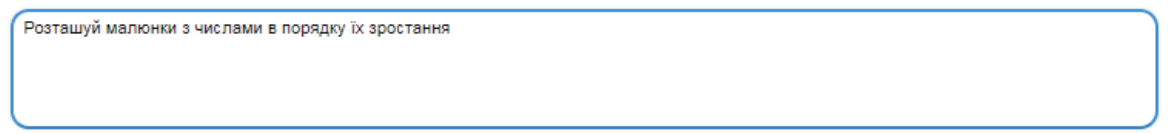

Картки

Вкажіть елементи, які будуть розміщені у зазначеному порядку. Порядок, вказаний на бланку е правильним рішенням.

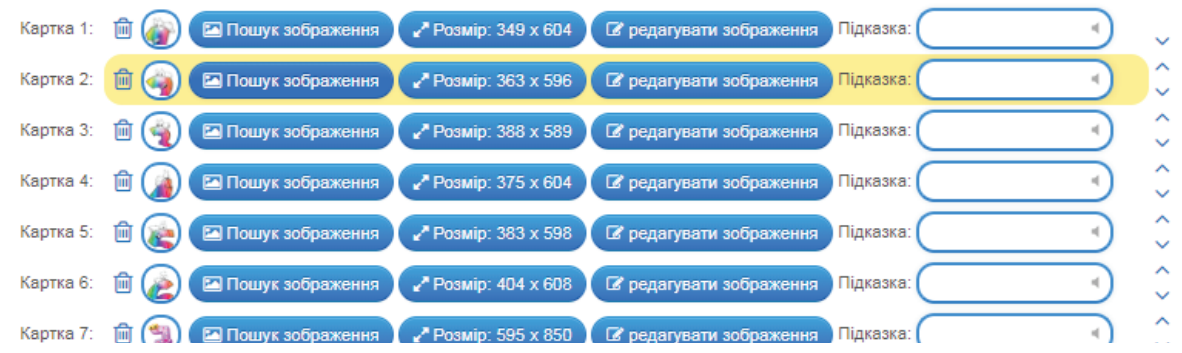

Figure 2. Filling in the "Easy Ordering" platform for Learning Apps.

S o u r c e : Own work.

By creating an exercise on the platform, the teacher can modify it: he or she can change the task of placing pictures with numbers in descending order or replace numbers.

In studying the numbering of the first ten numbers, the task (Skvortsova \& Onoprienko, 2017, p. 9) is executed on the "Numerical Line" platform, in which it is necessary to correlate the number of objects shown in the figures to the corresponding number (Figure 4). 


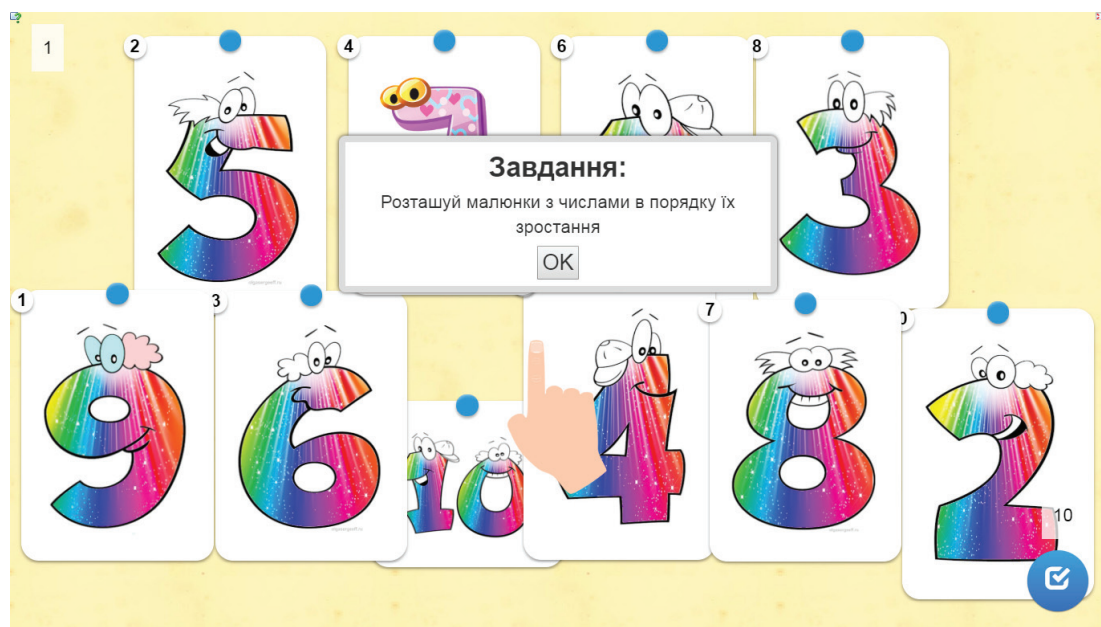

Figure 3. This interactive exercise was created using the "Easy Ordering" platform of the Learning Apps.

S o u r c e : Own work.

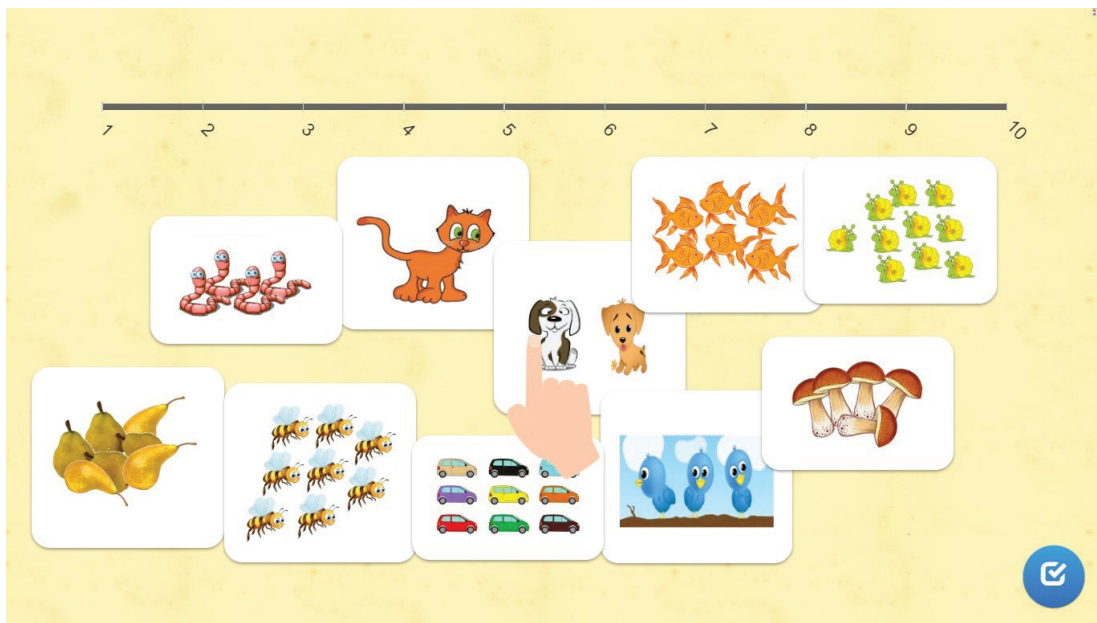

Figure 4. This interactive exercise was created using the "Numerical Line" platform of the Learning Apps.

S o u r c e: Own work.

If a student wishes to do it, he or she must first explore the pictures depicted on the screen and count the number of objects. Then the student correlates the number of depicted objects in the figures with the corresponding numbers, denoted by a numerical line. As soon as the child touches the drawing, a line joining the figure with the number appears. These actions must be performed with all the cards, and only then can the student click on the "check" button. 
Similar tasks are feasible for junior schoolchildren, as 6- and 7-year-old children are characterised by effective visual differentiation as they have developed visual perception (Bezrukih, 2011).

To implement algebraic and geometric propaedeutics, it will be best to use interactive exercises created on the "Find a Couple" platform. In order to create the abovementioned kind of exercise, it is necessary to select several pairs of two objects that correspond to each other, that is, they have a certain property. For the development of critical thinking of junior schoolchildren, the teacher has the opportunity to add superfluous elements that do not have a pair. For example, in the study of geometric figures, it will be effective to use interactive exercises in which students must explore all the geometric figures depicted on the screen and combine them into pairs on a common basis (Figure 5) (Skvortsova \& Onoprienko, 2017, p. 6).

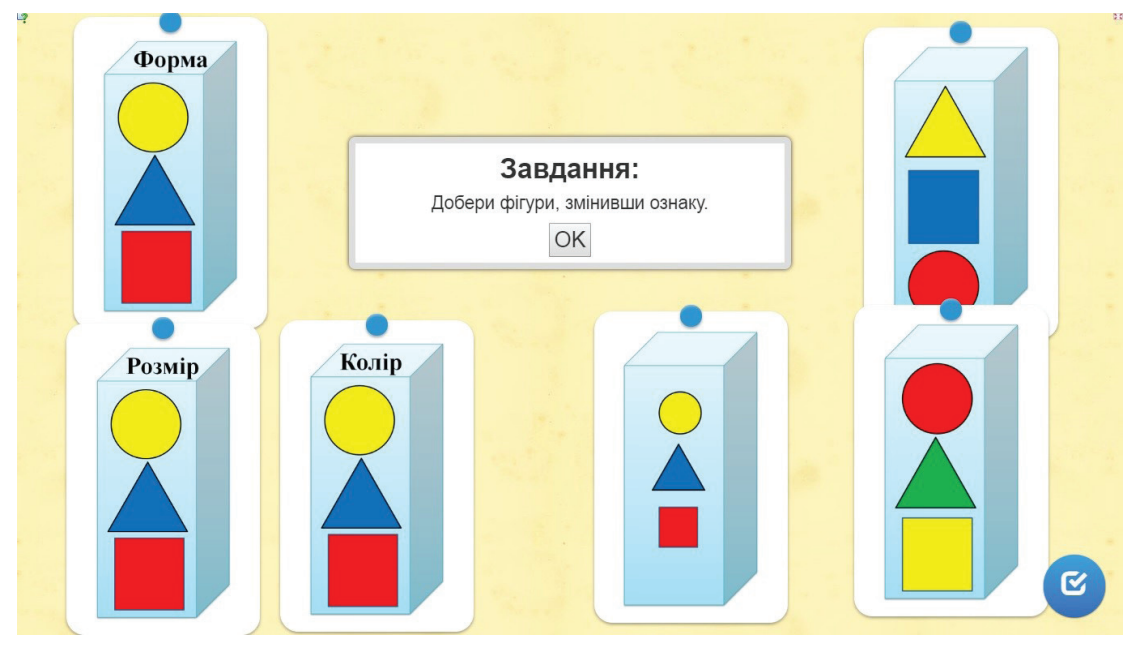

Figure 5. This interactive exercise was created using the Learning Pair: Find a Couple platform.

S ource : Own work.

Each interactive exercise created on the Learning Apps service has its own QR code, whereby a teacher can get a quick access to what he or she needs. In order to perform interactive exercises, it is enough for the teacher to place the QR code on any level surface (to be designed on a board or to print on a sheet of paper), while students with special programmes installed (QR QR-barcode scanner, Smart Scan - QR \& Barcode Scanner Free, QR Droid Code Scanner, etc.) need to scan the code and they will instantly access the exercise the teacher offers. The use of interactive exercises with QR codes allows the teacher to diversify the learning process, organise non-standard maths lessons (lesson-quest, lesson-quiz, etc.), and, as a result, increase the interest of junior pupils in learning mathematics. 
Note that besides creating interactive exercises, the Learning Apps service enables the teacher to create a virtual classroom, manage student accounts, choose a set of exercises for each class, and control their execution.

\section{Approaches to Teaching Future Teachers to Create Interactive Exercises with Learning Apps}

The analysis of neuroscience data on the development of cognitive processes in junior pupils, the Google Generation, suggests that in order to effectively educate modern children, we need to take their needs and opportunities into account; therefore, the search for IT-based learning tools is relevant. On the other hand, according to the results of the study, future teachers are aware of the need for new IT-based learning tools and they are willing to use them. However, in the course of studying the methodology of teaching mathematics, in none of 52 universities of Ukraine do the course programmes envisage the issue of IT-based learning tools.

It should be noted that future primary school teachers study disciplines that are the basis for learning IT-based maths training. These are, first of all, fundamentals of informatics, technical means of education, new information technologies, methodology for the application of computer technologies in the teaching of school course objects, and others. Therefore, in the course of teaching the methods of teaching mathematics, it is necessary, on the one hand, to demonstrate the practical use of IT both in lectures and in practical classes, and, on the other hand, to actively involve students in mastering modern means of teaching mathematics for junior pupils. To solve this problem, the teacher needs to combine the explanation of the methodological material with the IT capabilities and, in particular, to demonstrate the capabilities of the Learning Apps service for creating interactive maths exercises.

The purpose of the experimental work is to prepare future teachers of elementary school to use the Learning Apps service in the process of teaching mathematics of pupils of grades 1-4. At the first stage of the study, we demonstrated to the students the ready interactive exercises created in this service; students mastered working with them as users. The second step was to familiarise students with the capabilities of the Learning Apps service and the algorithm for working with it. During the conducted experiment, a lecture session was held on the topic "Creating interactive exercises for the teaching of mathematics of junior pupils using the Learning Apps service."

The third phase of the experimental work involved the practical training to create interactive exercises on various platforms of the Learning Apps service: "Find a Couple," "Classification," "Numerical Straight," "Simple Ordering," "Free Text Response," "Fragments of Image," "Quiz," and "Fill in the Gaps." At practical and laboratory classes, students under the guidance of a teacher gained the ability to create interactive exercises. To this end, we developed an algorithm for creating interactive exercises using the Learning Apps service: 1) select a task 
from a textbook or tutorial; 2) develop a methodology of work on tasks, observing the methodological approaches studied; 3) choose an appropriate platform; 4) design the possible actions when performing the task; 5) develop an algorithm for the student to perform the task; 6) make an instruction for the student; 7) create a comfortable student interface task; and 8) make a bright, interesting shell task for children.

Most students quickly and easily mastered the technique of creating interactive exercises in the Learning Apps service: they acquired the knowledge and ability to fill existing platforms by template. In the first lesson, some students encountered the difficulty of transferring an exercise from a textbook or a notebook to the Learning Apps service, that is, they could not pick up the platform for the exercise or chose the least appropriate of all. Students easily overcame these difficulties after getting acquainted with the peculiarities of each platform's work.

At the fourth stage, future teachers had to apply the acquired knowledge and skills of using the Learning Apps service while performing individual projects their own interactive mathematical exercises for students in grades 1-4 according to syllabuses (Skvortsova \& Onoprienko, 2017). Most students (92\%) coped with this task and created their own collection of interactive maths exercises for elementary students. $27 \%$ of students created an insufficient number of exercises, did all the exercises on the same platform, picked up the wrong platform, or filled it only with text information. $40 \%$ of students created all selected exercises technically correct, but the appearance of these exercises was not attractive and standard. $25 \%$ of the students came up creatively with interactive exercises, using their own images created in Paint or in PowerPoint. Some students proved that one can create interesting exercises with the same task using different platforms.

Individual projects performed by students were evaluated according to the following criteria: methodological, technical, and aesthetic. Indicators of the methodological criterion were the correctness of the methodological design of the task, the completeness of observance of the guiding basis of action, the clarity of the instruction for the implementation of the task for children, the ability to perform actions with the elements of the task. The technical criterion was characterised by the following indicators: optimality of the choice of the platform for the task implementation, correctness of settings, dynamism. The indicators of the aesthetic criterion were: external attractiveness (brightness, curiosity and contemporaneity of pictures, location on the plane of the task elements), observance of the colour gamut which causes positive emotions in children, sound support (use of pleasant sound signals, musical accompaniment, etc.).

Determining the above indicators of methodological and technical criteria made it possible to characterise the levels of development of interactive tasks using the Learning Apps service:

- low: there is fragmentary knowledge and ability to create interactive exercises with the help of a teacher; 
- average: the student has certain theoretical knowledge about the service and is able to perform the practice according to the model;

- sufficient: the student knows the features of each platform and is able to create standard exercises using images, and audio and video clips; and

- high: the student knowledge is a deep, strong system; the future teacher is able to apply this knowledge for non-standard creation of exercises and selfdevelopment.

Therefore, it is necessary for the teacher of the methods of teaching mathematics course, on the one hand, to demonstrate the practical use of IT in lectures and in practical classes, and, on the other hand, to actively involve students in mastering modern means of teaching mathematics for junior pupils.

Basing on student self-assessment (Figure 6), it can be argued that almost all students acquired the knowledge and skills to create interactive exercises in the Learning Apps service; only $8 \%$ demonstrated a low level of interactive skills with the use of Learning Apps (Figure 6). This situation can be explained by the fact that these students were absent at most classes, gaining knowledge and skills in creating interactive exercises in the framework of an individual schedule, or that they did not have a desire to gain these skills on their own.

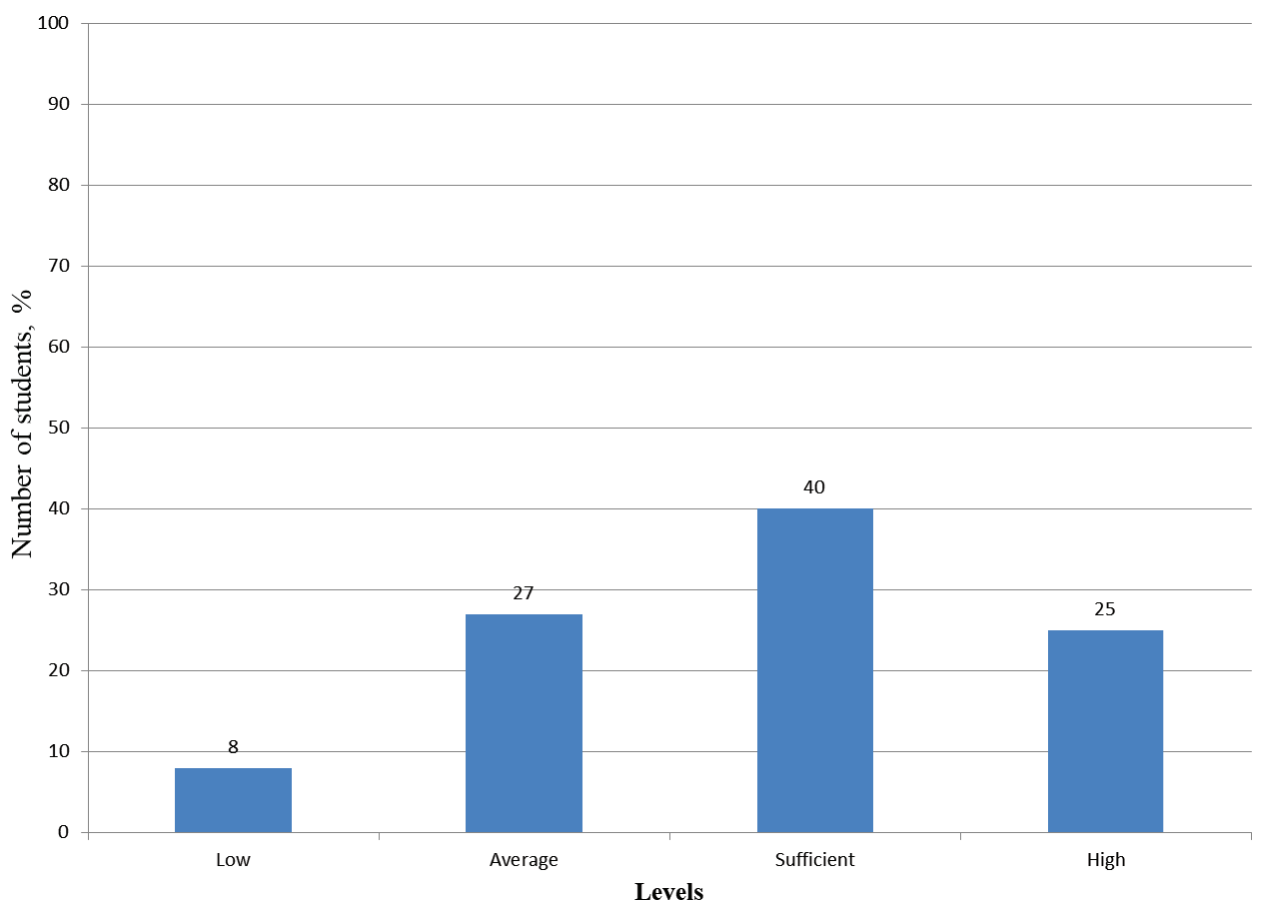

Figure 6. Results of an evaluation of interactive exercises created by students using the Learning Apps service.

S o u r c e: Own work. 


\section{Conclusion}

The introduction of IT in the teaching of mathematics of modern junior pupils means changes in the system of training future teachers. When preparing for future professional activities, students must be aware of the means by which they can organise student learning activities.

In the course of experimental work, the state of preparation for the use of IT by future teachers of primary school was researched. It has been found that most students have basic knowledge, skills, IT skills, and readiness to improve them and, in particular, to learn how to create interactive exercises with the Learning Apps service.

We have developed a system for preparing students to create interactive exercises using the Learning Apps service, which includes the following steps: demonstration of the finished interactive exercises, familiarisation with the capabilities of the Learning Apps service and the algorithm of working with them, practical training to create interactive exercises on various platforms of the service, students' performance individual projects. As a result of the experimental training, $92 \%$ of students mastered the ability to create interactive exercises with the help of Learning Apps.

We see prospects for further research in the creation of a bank of interactive exercises in mathematics; we wish to acquaint future primary school teachers with other online resources and online learning services for mathematics, namely Moodle, Google Forms, Webanketa, Online Test Pad, GoConqr, PlayBuzz, Baamboozle, Kahoot!, Triventy, Socrative, Quizalize, ProProfs, Purpose Games, H5P, Flippitty, and so on.

\section{References}

Bezrukih, M. M. (2003). Vozrastnaâ fiziologiâ (Fiziologiâ razvitiâ rebenka). Moscow: Izdatel'skij centr Akademiya.

Bezrukih, M. M. (2011). Doškol'nik. Mify i realii razvitiâ. Vestnik praktičeskojpsihologii obrazovaniâ, $4(29), 16-20$.

Goncharenko, S., Vavrik, A., \& Vereshchak, O. (2014). Psihologična diagnostika osoblivostejkognitivnogo rozvitku molodših školârìv v umovah informacìnogo. Kyiv-Kirovograd: Imeks-LTD.

Hielscher, M. (2012). Autorenwerkzeuge für digitale, multimediale und interaktive Lernbausteine im Web 2.0. Dissertation zur Erlangung des Grades eines Doktors der wirtschaftlichen Staatswissenschaften /Doctoral dissertation/. Johannes Gutenberg-Universitet Mainz.

Kim, D., Dunphy, P., Briggs, P., Hook, J., Nicholson, J. W., Nicholson, J., \& Olivier, P. (2010). Multitouch authentication on tabletops. In: Proceedings from the $28^{\text {th }}$ International Conference on Human Factors in Computing Systems (pp. 1093-1102). New York: ACM. 
Kirschner, P. A., Wopereis, I. G. J. H., \& Van den Dool, P. C. (2002). ICT3: Information and communication technology for teacher training: Pedagogic benchmarks for teacher education. Utrecht: Inspectie van het Onderwijs.

McLuhan, M. (1962). The Gutenberg galaxy: The making of typographic man. Toronto: University of Toronto Press.

National Centre for Technology in Education. (2008). Continuing Professional Development Initiative. Accessed 1 September 2018. Retrieved from http://test.ncte.ie/NCTEInitiatives/ ContinuingProfessionalDevelopment.

Proposal for a Council recommendation on key competences for lifelong learning. (2018). Accessed 1 September 2018. Retrieved from https:/ec.europa.eu/education/sites/education/files/ recommendation-key-competences-lifelong-learning.pdf.

Ŝo take Web? Web 3.0? Ŝo ce? ? (2009). Accessed 1 September 2018. Retrieved from http://ekzamen. blogspot.com/2009/01/web-ibm-web-3.html.

Skvortsova, S. O. \& Haran, M. S. (2014). İnformacìjnì tehnologii âk zasìb opanuvannâ studentami navčal'noï disciplìni Metodika navčannâ osvìt osìtn'oï galuzì «Matematika» Ìnformacìjnì tehnologiï v osvìtì. 2014. 21, 37-44. DOI: 10.14308/ite000509. https://skvor.info/publications/ articles/view.html?id=204

Skvortsova, S. O. \& Haran, M. S. (2015). Zastosuvannâ mul'timedìnih tehnologìj u procesìopanuvannì studentami navčal'noï disciplìni Metodika navčannâ osvìtn'oï galuzì «Matematika». Vìsnik Čerkas'kogo unìversitetu. Serîa: pedagogičnì nauki, 141, 19-25.

Skvortsova, S. O. \& Onoprienko, O. V. (2017a). 1 klas. Navčal'nij zošit: U 3 častinah. Častina 1. Kharkiv: Ranok.

Skvortsova, S. O. \& Onoprienko, O. V. (2017b). 1 klas. Navčal'nij zošit: U 3 častinah. Častina 2. Kharkiv: Ranok.

Smyrnova-Trybulska, E., Stec, M., Studenska, A., Noskova, T., Pavlova, T., Yakovleva, O., \& Cubo Delgado, S. (2017). Glossary of terms for ICT and e-learning: Compare the Polish, Spanish and Russian approach. In Proceedings from the Scientific Conference on Theoretical and Practical Aspects of Distance Learning - Effective Development of Teachers'Skills in the Area of ICT and E-learning, 16-17 October 2017 (pp. 105-119). Katowice.

Sparrow, B., Liu, J., \& Wegner, D. M. (2011). Google effects on memory: Cognitive consequences of having information at our fingertips. Science, 333, 776-778.

Zhaldak, M. I. (2005).Pro deâkì metodičnì aspekti navčannâ ìnformatiki v školì ta pedago-gičnomu unìversitetì. Naukovì zapiski Ternopil's'kogo nacional'nogo pedagogičnogouniversitetu. Serîa. pedagogika, 6, 17-24.

Svetlana Skvortsova, Tetiana Britskan

\title{
Kształcenie kandydatów na nauczycieli szkół podstawowych do wykorzystania aplikacji Learning Apps w nauczaniu matematyki
}

\author{
Streszczenie
}

Artykuł jest poświęcony zbadaniu problemu przygotowania kandydatów na nauczycieli szkół podstawowych do wykorzystania technologii informacyjnej (IT) w nauczaniu matematyki, szczególnie w zakresie stosowania dostępnych online zasobów i usług dla nauczycieli oraz oprogramowania edukacyjnego. Dokonano analizy rezultatów diagnozy warunków kształcenia przyszłych nauczycieli 
pod względem wprowadzania technologii informacyjnych na lekcjach matematyki w szkole podstawowej. Określono cechy charakterystyczne dzieci z pokolenia cyfrowego. W oparciu o uzyskane wnioski uzasadniono konieczność wprowadzenia technologii informacyjnej na lekcjach matematyki. W końcu zidentyfikowano podejście oparte na kształceniu kandydatów na nauczycieli do tworzenia ćwiczeń interaktywnych, zwłaszcza poprzez dostępny online serwis Learning Apps.

S ło w a k lu c z o w e: technologia informacyjna, szkolenie przyszłych nauczycieli, serwis internetowy Learning Apps, ćwiczenia interaktywne

Svetlana Skvortsova, Tetiana Britskan

\title{
Подготовка будущих учителей начальной школы к использованию сервиса Learning Apps в процессе обучения математике
}

Анно т а ия

Статья посвящена исследованию проблемы подготовки будущих учителей начальной школы к использованию информационных технологий (ИТ) в обучении учащихся математике, в частности, в аспекте использования различных онлайн ресурсов, онлайн сервисов для учителей и других педагогических программных средств. Проанализированы результаты диагностики состояния подготовки будущих учителей к внедрению ИТ на уроках математики в начальной школе. Выяснены особенности цифрового поколения детей, и, исходя из этого, обоснована необходимость внедрения ИТ на уроках математики. Определены подходы к обучению будущих учителей создавать интерактивные упражнения, в частности с помощью онлайн сервиса Learning Apps.

К л ю ч е в ы е с л о в а: информационные технологии, подготовка будущих учителей, онлайн сервис Learning Apps, интерактивные упражнения

Svetlana Skvortsova, Tetiana Britskan

\section{Formación para futuros profesores de escuela primaria en uso de servicio aplicaciones de aprendizaje en matemáticas}

\author{
Resumen
}

Este artículo investiga la formación de futuros docentes de primaria en el uso de la tecnología de la información (TI) en la enseñanza de las matemáticas, en particular, en el uso de diversos recursos en línea, servicios en línea para docentes y otro tipo de software pedagógico. Se analizan los resultados del diagnóstico de una condición de la formación de futuros profesores para la implementación de las TI en las clases de matemáticas en primaria. Se han determinado las peculiaridades de la generación de niños nativo-digitales y, en base a esto, se ha corroborado la necesidad del uso de TI en las asignaturas de matemáticas. Además, se han identificado los enfoques para capacitar a futuros docentes para crear ejercicios interactivos, en particular a través de Learning Apps. 
P a labras c lave: tecnología de la información, formación de futuros profesores, sitio web de Learning Apps, ejercicios interactivos 